\title{
2
}

\section{Ganges-Brahmaputra-Meghna Delta, Bangladesh and India: A Transnational Mega-Delta}

Md. Munsur Rahman, Tuhin Ghosh, Mashfiqus Salehin, Amit Ghosh, Anisul Haque, Mohammed Abed Hossain, Shouvik Das, Somnath Hazra, Nabiul Islam, Maminul Haque Sarker, Robert J. Nicholls and Craig W. Hutton

\subsection{The Ganges-Brahmaputra-Meghna Delta}

The Ganges-Brahmaputra-Meghna (GBM) Delta at the north of the Bay of Bengal is administrated by both India and Bangladesh. It is characterised by a number of livelihood opportunities resulting from high population density, as well as a number of biophysical and socioeconomic challenges (flooding, erosion, cyclones, salinisation, water logging, etc.) which are increasing alongside the changing climate and anthropogenic developments.

M. M. Rahman $(\bowtie) \cdot$ M. Salehin · A. Haque · M. A. Hossain Institute of Water and Flood Management, Bangladesh University of Engineering and Technology, Dhaka, Bangladesh e-mail: mmrahman@iwfm.buet.ac.bd T. Ghosh · A. Ghosh · S. Das · S. Hazra

School of Oceanographic Studies, Jadavpur University, Kolkata, India

N. Islam

Bangladesh Institute of Development Studies, Dhaka, Bangladesh 
The people of this region are mainly dependent on the agricultural sector, while people living in the coastal belt are dependent on traditional monsoon rice cultivation as well as livelihood activities such as riverine and marine fishing and activities related to mangroves such as honey collection. Freshwater flooding is a common occurrence in the delta during the monsoon; it generates benefits such as increased soil fertility, aquifer recharge, replenished ecosystem and increased agricultural production. The delta also supports a diversity of ecosystem services that attract and support a large local population. One key area is the Sundarbans, the world's largest mangrove forest, covering $10,000 \mathrm{~km}^{2}$ which is shared between Bangladesh (60\%) and India (40\%) (Fig. 2.1). The unique biodiversity of this area supports a diversity of livelihood options for the people living on its periphery (Gopal and Chauhan 2006).

The coastal population is exposed to climate hazards, including fluvio-tidal floods, tropical cyclones accompanied by storm surges, river bank erosion, salinity intrusion due to seasonal low flow levels in rivers and upstream water diversion, high levels of salinity in groundwater and arsenic contamination of shallow aquifers. Climate change and land use impacts are expected to reinforce many of these stresses (Dastagir 2015). These environmental stresses are believed to be enhancing already substantial displacement and migration. However, while the country has seen many planned and autonomous adaptations to minimise forced migration and displacement, situations often arise when people have little choice but to move (Mortreux et al. 2018). Consequently, for effective planning, it is important for policymakers

M. H. Sarker

Center for Environmental and Geographic Information Services,

Dhaka, Bangladesh

R. J. Nicholls

School of Engineering, University of Southampton, Southampton, UK

C. W. Hutton

GeoData Institute, Geography and Environmental Science,

University of Southampton, Southampton, UK 


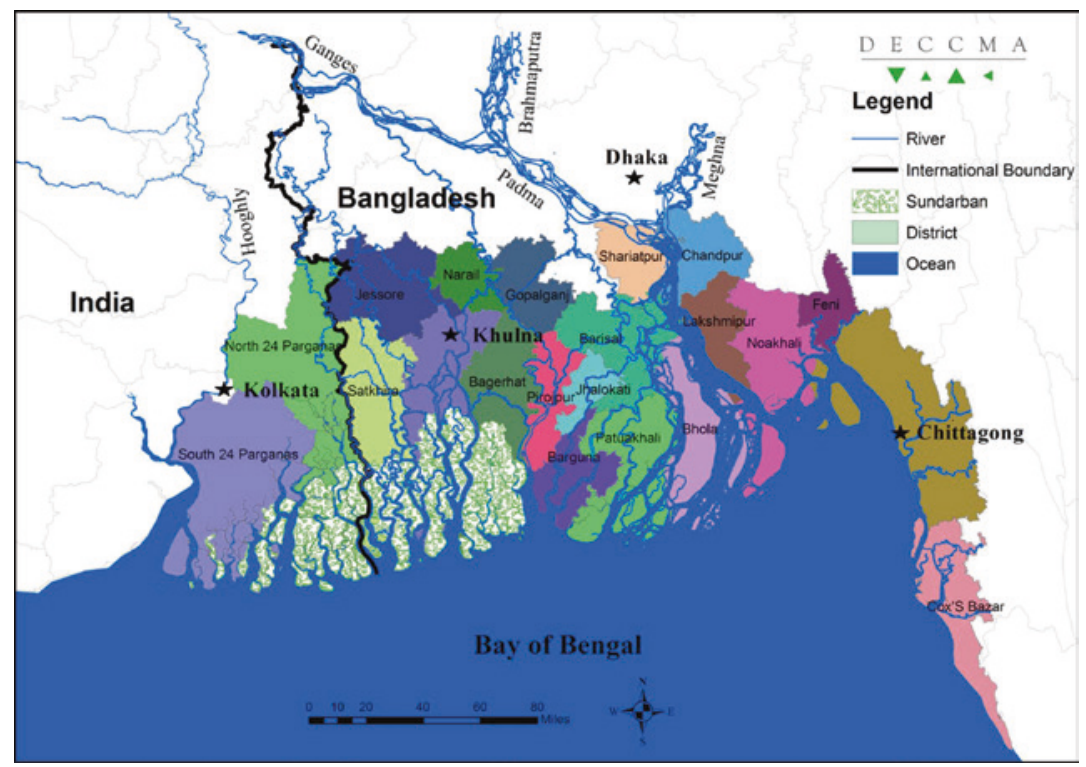

Fig. 2.1 The Ganges-Brahmaputra-Meghna Delta showing the coastal zone with administrative districts in both India and Bangladesh

to have an understanding of how effective adaptation options are, the circumstances under which people migrate, and if or when people see migration as an option in the context of available adaptation choices (Chapter 7).

Coastal Bangladesh has an extensive system of coastal embankments and polders built since the 1960s with the goal of reducing flooding/salinity, managing water levels and enhancing agriculture (Haque and Nicholls 2018). While the positive results from such interventions are visible in the form of increased agricultural production and enhanced regional connectivity, these benefits could not be translated into long-term gains across the GBM system (Noor 2018). Rather, these interventions are posing substantial challenges. Prolonged water logging due to silting up of river beds and hence reduced drainage capacity of floodplains, further exacerbated by ill-planned or ill-executed infrastructure projects, such as internal road system, water control infrastructure not being properly maintained and 
aquaculture and other economic activities obstructing drainage undermine the provision of sustainable services. In addition, they contributed to land subsidence, land use pattern changes and tidal influences on flooding (Islam et al. 2010).

The study area in this chapter considers the part of the delta that is most threatened by sea-level rise. In West Bengal, this corresponds to the political units that include areas below $5 \mathrm{~m}$ elevation near KolkataSouth 24 Parganas and North 24 Parganas (Fig. 2.1). In Bangladesh, the area below $5 \mathrm{~m}$ extends across much of the country and the study area corresponds to coastal Bangladesh as defined by the Government of Bangladesh. The study area includes part of the Kolkata metropolitan area, but excludes Dhaka: both these cities attract significant migration (see Chapter 1, Table 1.4). The population of the study area is 57 million and occupies more than $51,500 \mathrm{~km}^{2}$. When compared to other papers such as Ericson et al. (2006) and Woodroffe et al. (2006) which consider the entire Holocene surface rising to $20 \mathrm{~m}$ elevation and a population exceeding 100 million people, it is apparent that the focus here is more coastal than in earlier analyses.

The aim of the chapter is to consider the whole of the coastal GBM Delta in India and Bangladesh from a biophysical and socio-economic perspective. There is a focus on the Anthropocene delta and its prospects and the consideration of both India and Bangladesh makes the chapter distinct compared to most analyses which are delimited by national boundaries. The chapter is structured as follows. The characteristics of delta-building and socio-ecological processes are outlined, followed by discussion on emerging opportunities and challenges, growth of settlements/land use, vulnerability mapping and options for adaptation, including migration.

\subsection{Morphological Evolution of the Delta}

The GBM Delta is a peripheral foreland basin formed through continent-continent collision formed over many millions of years (Raman et al. 1986). Physiographically, the GBM Delta can be divided into two major units - the Pleistocene uplands and the deltaic lowlands. There 
are four major terraces; two of these terraces flank the basin extending east of the Rajmahal hills and west of the Tripura Hills while the other two, Barind and Madhupur Forest, lie within the basin (Morgan and McIntire 1959). The other main physiographic division of the GBM Delta system is the Holocene alluvial plain and the delta.

Pleistocene eustatic sea-level fall has created widespread terraces and deep erosion of valleys by lowering of base level (Alam 1996). The sediments brought in by the Ganga-Brahmaputra system during the post-Pleistocene period appear to have mainly bypassed the delta and contributed to the rapid growth of Bengal deep-sea fan (Biswas 1992). Holocene sediments are found in the alluvial fans in the foothills of the Himalayas, the uplands such as the Tippera surface, the deep tectonic basin (Sylhet basin) and the GBM flood and delta plain, the most extensive unit of the GBM Delta.

Allison et al. (2003) examined the mineralogical properties of sediment for assessing sedimentary sequence resulting from the lower delta plain progradation in the late Holocene. From a series of 38 core sites across the delta, clay mineralogical and radiocarbon evidence agree that the lower delta plain progradation after the maximum transgression may have been in six phases as the Ganges and Brahmaputra grew together (Fig. 2.2). Clay mineralogy suggests an increasing influence of the Ganges in the upper section that may suggest a progradation of Ganges distributaries into the westernmost delta in the earliest phase (G1). The early (5000 cal years BP) deltas of the Brahmaputra (B1) and the Ganges were located far inland of the present shoreline, reflecting the large amount of accommodation space available in the tectonically active Bengal basin. Allison et al. (2003) also found that the shoreline progradation associated with the two rivers was separate from 5000 cal years BP until they merged into the present Meghna estuary as recently as about 200 years ago. A series of eastward steps of the Ganges occurred in three main phases (G1-G3). In each phase, delta progradation occurred over a wide front that encompassed several active island-shoal complexes. On the other hand, delta plain formation of the Brahmaputra occured inland along two loci created by channel avulsions east and west of the Pliestocene Madhupur terrace. The Sylhet basin, in the east of the Bengal delta, faced southward into 


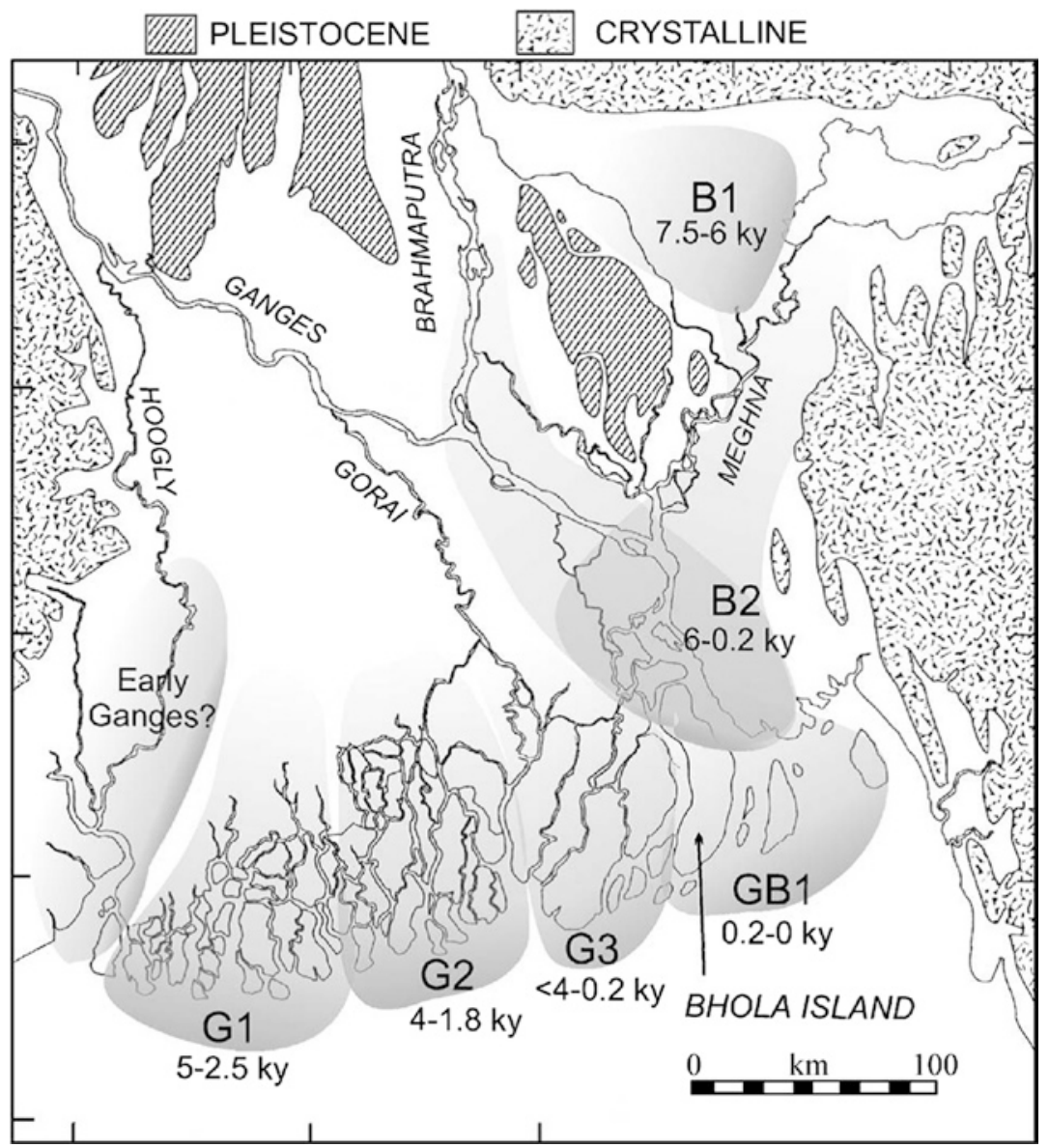

Fig. 2.2 Paleo-geographic map and the pathways and timing of the phases of late Holocene growth of the lower delta plain associated with the Ganges (G1, G2, G3), Brahmaputra (B1, B2) and combined Ganges-Brahmaputra (GB1) Deltas (Adapted from Sarker et al. 2013)

the Meghna estuary following the Meghna River course. Delta progradation into the Meghna estuary (GB1) was limited until the two rivers, the Ganges and the Brahmaputra, met in historical times. This progradation direction matches well with the findings of Goodbred and Kuehl (1998). 
Consistent with the evolution of the river system during the Holocene, the rivers have changed course several times during the last centuries (Fig. 2.3). About 250 years ago (in 1776), the Brahmaputra River flowed east side of the Madhupur Tract to meet the Meghna River, and then into the Bay of Bengal, with the Bhola district on its west. Till then the Padma River was simply the downstream continuation of the Ganges River. At that time, the Ganges entered the Bay of Bengal along the approximate course of the Arial Khan River keeping Bhola island on its east (Fig. 2.3). All the distributaries in this region along with the Ganges River were flowing southeast in that period. The Chandana- Barasia, a southeast flowing river, was the main source of freshwater for the southwest region with a small link with the Gorai River. The Kabodak River was connected by a narrow link to the Ganges. When the Brahmaputra avulsed to the present Jamuna in the early nineteenth century and merged with the Ganges, it caused many significant changes to the river systems (Fig. 2.3, 1776-1840) in the southwest region of Bangladesh.

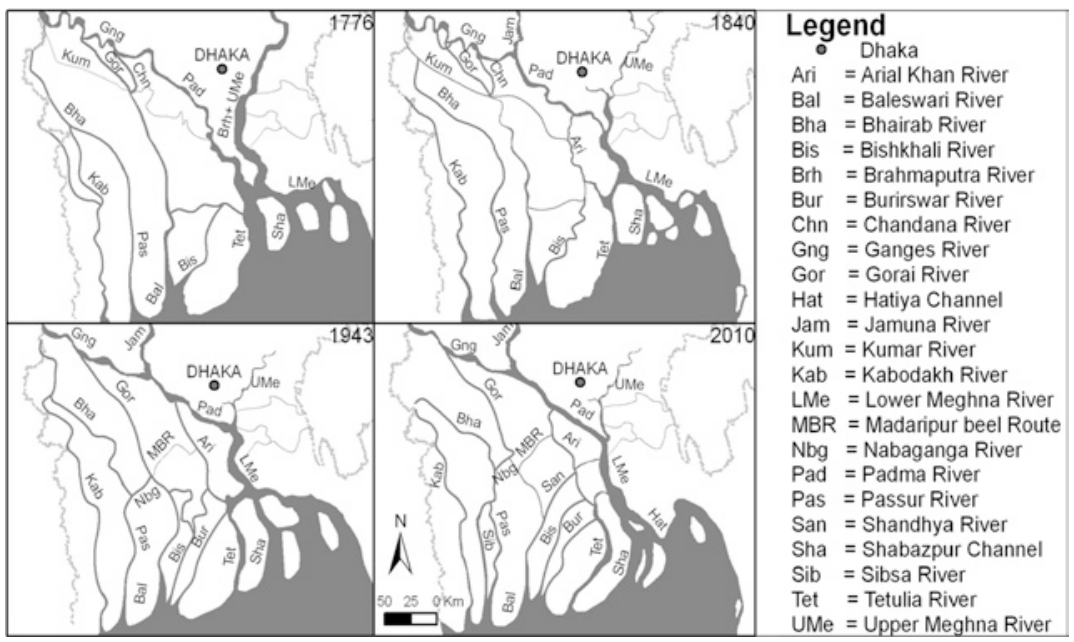

Fig. 2.3 Development of the main rivers in Bangladesh from 1776 to 2010 (Adapted from Sarker et al. 2013) 
During the last 250 years, the location of the delta-building estuary has moved eastward. In the same period the distributaries, which also contribute in the delta-building processes, shifted their courses to the southwest direction, the dominating direction of which was mainly southeast about 200 years ago (Sarker et al. 2013).

Currently, the GBM Delta is fed and drained by the rivers Ganges, Brahmaputra and Meghna, along with their numerous tributaries and distributaries. The Ganges River drains the Himalayas and a significant portion of Northern India for approximately $2500 \mathrm{~km}$ before entering the Bengal basin and dividing into two distributaries. The main stem of the Ganges continues flowing southwards where it meets the Brahmaputra River. The other stem flows through West Bengal in India as the Bhagirathi-Hoogly River (Fig. 2.1). Cumulative river water discharge through the GBM Delta is the fourth largest in the world (Milliman and Meade 1983) and the delta is the world's largest sediment dispersal system (Kuehl et al. 1989). It has been estimated that about $10^{3}$ million tonnes of sediment per year pass through to the Bay of Bengal across the $380 \mathrm{~km}$ delta front (Allison 1998), although analysis of recent sediment flux suggests a reduction by $50 \%$ with a decreasing trend (Rahman et al. 2018). The GBM Delta has a mean rate of subsidence of $3.9 \mathrm{~mm} / \mathrm{yr}$ (Brown and Nicholls 2015). This translates into an average relative sea-level rise, including climate-induced rise, of about $7 \mathrm{~mm} / \mathrm{yr}$ over the last few decades, although there is spatial variability.

\subsection{Delta Development During the Anthropocene}

The modern history of settlements in this region dates back to 1757 when land passed from local landowners to the East India Company, who began reclamation in the Sundarbans for rice fields through direct leasing of land to local farmers who enclosed sections of land. In 1839, rights for forest land with 99 years lease agreements known as 'Latdars' or tenure holders were also issued, with land sales initiated in 1865. In the precolonial period most of the pasture lands of rural Bengal were 
under the control of the village community. However, during the colonial period (post 1757), pressure of population and permanent settlement generated changes. Land came under the control of revenue collectors known as Zamindars, Jatdars, and Jaigirdars who, with supportive state intervention, converted pasture land into cultivated land. Consequently, during this period the delta population remained reliant on mainly small-scale agricultural productivity (see Ghosh 2017).

\section{Infrastructure Development}

The advent of the Anthropocene (after 1950) coincides with Independence for India from the British Empire in 1947. In the postcolonial era, many large river dams were built across Indian rivers to facilitate either irrigation or power generation (Alley et al. 2014); interception of the rivers and construction of reservoirs being regarded as the most convenient method of water storage. One of the clear changes in the delta since this date is that more than five thousand dams have been built in the upper catchments, submerging extensive areas in the upper delta and, with them, the homelands of at least 40 million people. However, the benefits of projects, be it irrigation or hydropower, were generally enjoyed by the people living in the lower catchment. In addition, the delineation of the Indo-Bangladesh border resulted in 54 rivers including the Ganga becoming transboundary rivers, leading to conflicts around the sharing of water.

The commissioning of the Farakka Barrage on the Ganga in India in 1975 (Fig. 2.1) was expected to improve the status of the navigation channel approaching the port of Kolkata as the water diverted from the Ganga to the Bhagirathi was expected to reduce the sedimentation in the estuary and ensure better draught for the ships. However, this did not occur and sedimentation remains an unsolved problem (Rudra 2018). This was closely followed by the Teesta Barrage Project (TBP), conceived by the Irrigation and Waterways Department, Government of West Bengal in 1976, with the vision of irrigating around 1,000,000 ha of land. Seven hydropower stations, four in Sikkim and three in West Bengal, on the Teesta and its tributaries have 
been constructed to date. The fluctuation of flow has affected flora and fauna downstream (Rudra 2018). Construction of major engineering projects has continued. Following the Gazoldoba Barrage in India (1987), Bangladesh constructed a barrage at Duani (Lalmonirhat district) in 1990. As in the development of the TBP, the planners did not consider available water at the barrage site. Consequently, there remained a wide gap between the potential benefits and the area actually irrigated. As such, the project only provides supplementary irrigation to the Kharif crop during mid-monsoon breaks. These represent a few examples of how historical river interventions have influenced the hydrological regime and delta development of the GBM during the Anthropocene.

\section{Population and Land Use}

The Anthropocene has seen a rapid increase in population for the combined GBM Delta (Fig. 2.4) and changes in land character (see Figs. 2.5 and 2.6), although it remains one of the most under-developed areas in both Bangladesh and India. The population is mostly dependent on traditional monocrop (Aman paddy/rice) cultivation and riverine/offshore fishing, crab collection, honey collection, among other livelihoods. The recent decline in agricultural productivity, linked with poverty, is increasing the movement of migrants out of the delta for dominantly economic reasons (Adger et al. 2018; Hajra and Ghosh 2018). However, the percentage of urban population is increasing gradually (now around $27 \%$ of total) and this is contributing towards urbanising the delta, leading to changes in land use.

A key characteristic of the Anthropocene delta has been the progressive land use change driven by the introduction of large-scale aquaculture, partially for financial reasons and partially in response the progressive increase in salinity driven by rising sea-levels and hydrological mismanagement in the upper delta systems. The terrestrial forest and water-based ecosystem services play a major role in the livelihood of the people, and gradual depletion impacts the traditional farm-based economy. In the Indian part of the GBM Delta, the initial land conversion 


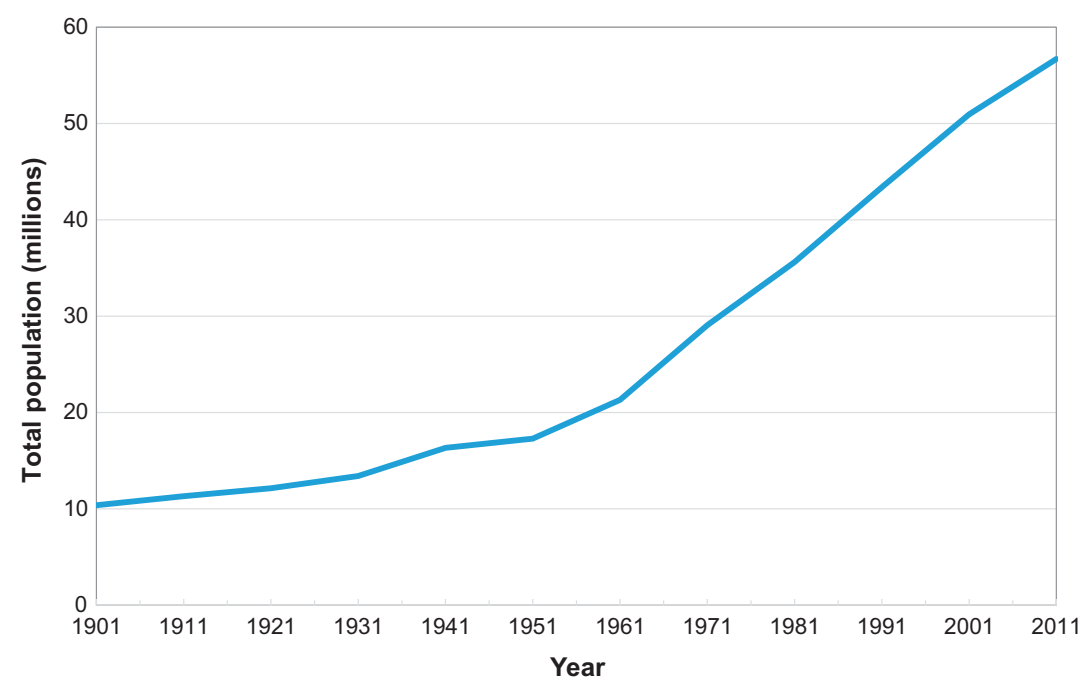

Fig. 2.4 Total population over time in the combined GBM Delta showing the rapid growth, post 1950, during the Anthropocene (Data from Census of India [2011], BBS [2015])

was from mangroves to agriculture and human settlement and, following a decline in agriculture, conversion to aquaculture and brickfields (Fig. 2.5). Saline water aquaculture also gained popularity because of increased water salinity and soil salinity. Because of the lack of leaching activities and continuous increase of salinity, productivity decreased gradually and land is no longer suitable for freshwater aquaculture. Finally, the land became only suitable for brickfields. This is one visible example of the impacts of unplanned land conversion in the Indian part of the GBM Delta. The Bangladesh part of the delta experienced a decline in agricultural area associated with a rapid increase in total built-up area and aquaculture as illustrated in Fig. 2.6. Aquaculture has grown in the southwest exploiting the saline water environment, with large economic returns, but at the expense of severe degradation of soil. There has been some increase in agricultural development in the southwest part of Bangladesh where improved drainage provides opportunities for new agriculture. Increases in planted mangrove areas and mudflats are 


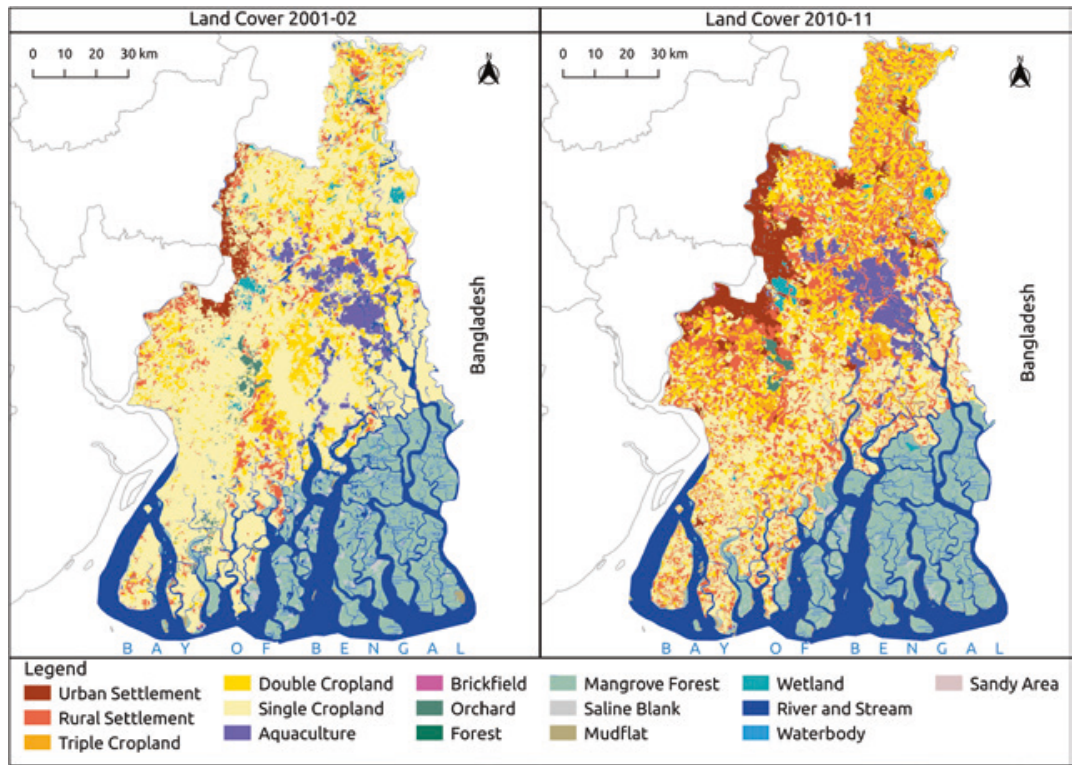

Fig. 2.5 Land use change in the Indian section of the GBM Delta showing the increase in urban settlements, decrease in agricultural land and area of land converted to brickfields

apparent, especially within Meghna Estuary. Increase in mudflat area is a manifestation of the active delta-building process, while increase in mangrove area on mudflats represents the increasing focus of the government on coastal afforestation. These new areas are being explored for industrial intensification through special economic zones, which target high growth and employment. The delta-building process in the GBM is thus opening further dimensions for human intervention in the delta during the Anthropocene, especially in Bangladesh.

\section{Policy and Governance Interventions}

India and Bangladesh have faced difficulties in cooperating to achieve policy formulation and management of the GBM Delta in the Anthropocene. The transboundary issues can be traced back to the formation of Bangladesh 


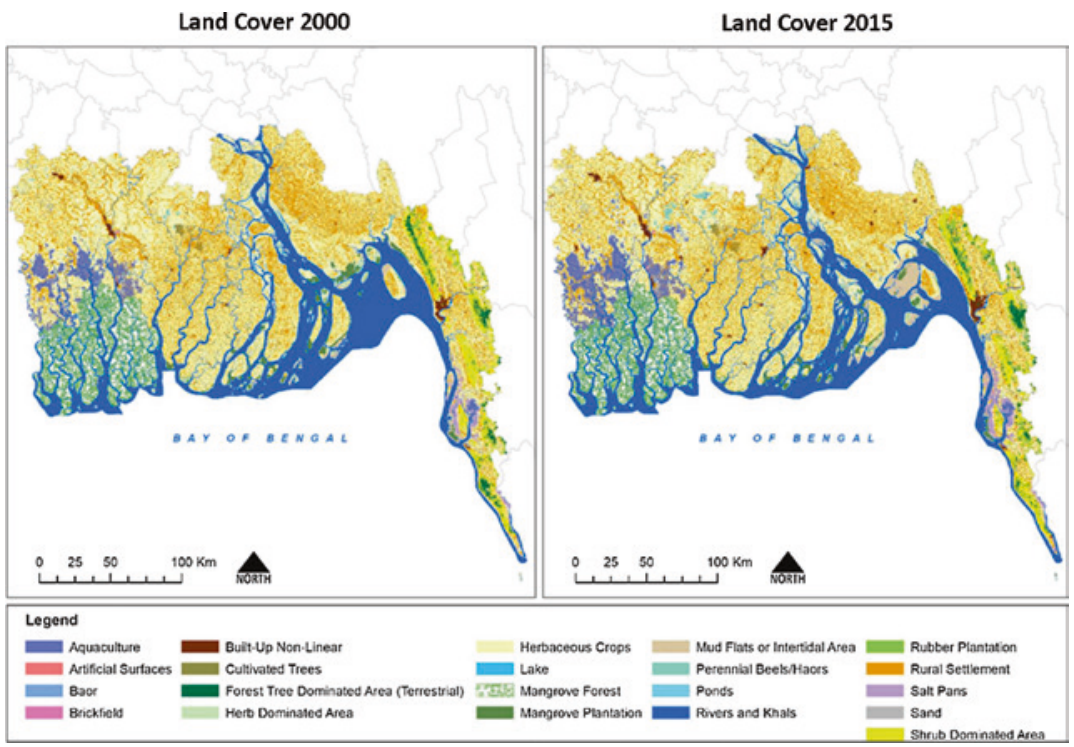

Fig. 2.6 Change in land use in the Bangladesh portion of the GBM Delta from 2000 to 2015 (see DECCMA 2018)

(1971) and, despite sharing fifty-four rivers with India, Bangladesh only signed the Ganges Treaty with India in 1996 with India removing the arbitration clauses with respect to minimum water requirements. Water sharing agreements should be implemented with comprehensive policy dialog, ensuring the principles of equity and fairness. The formation of the IndoBangladesh Joint River Commission (JRC) has not improved the situation, with blockage or diversion of river water not discussed between the two countries. For example, the construction of the Farakka Barrage in 1975 led to a sharp decline of the freshwater supply to the Ganges River during the dry season, adversely affecting agriculture, navigation, irrigation, fisheries and allowing salinity intrusion within Bangladesh.

Governments, non-governmental bodies and foreign organisations have been identifying innovative approaches to help the delta populations adapt to change and to reduce vulnerabilities in the face of future uncertainties. National Adaptation Programme of Action 2005, Bangladesh Climate Change Strategy and Action Plan 2009 (BCCSAP 2009) and 
Bangladesh Climate Change and Gender Action Plan 2013 (BCCGAP 2013) are some of the guiding documents for planned adaptation strategies formulated by the Government of Bangladesh (Haq et al. 2015). Various climate change adaptation issues have been addressed to different extents in sectoral policies of Bangladesh with regards to dimensions such as risk reduction, community- and ecosystem-based adaptation, migration and gender. The National Action Plan on Climate Change (NAPCC) of 2008 and 2014 and the West Bengal State Action Plan on Climate Change (WBSAPCC) of 2012 have been the guiding documents in the Indian part of the delta. A total of seven (agriculture, wind, energy, health, waste to energy, health and coastal areas) out of twelve missions stated in the NAPCC promote adaptation, while the WBSAPCC marks the first integrated plan to combat climate change phenomenon in the Indian part of the delta (Dey et al. 2016). In both parts of the delta, the sectoral policies and plans have tended to be short term and sector-specific, following the mandate of the formulating ministries or departments, while clearly lacking integration across relevant issues including the cross-cutting issues. There is a clear need for a framework to allow coordination among the sectoral approaches from climate change perspective by setting sectoral priorities and identifying key sectors for immediate attention (Haq et al. 2015; Dey et al. 2016; Salehin et al. 2018).

In Bangladesh, awareness of gender emerged in policies and plans most notably after 2009. Although female empowerment is emphasised in areas such as disaster preparedness and management activities, agriculture management and agriculture wages, there is no explicit link between gender-specific needs in the climate change context. There is a lack of guidelines for gender-specific adaptation; policies and plans which address gender issues discuss 'what to do' but not 'how to do'. BCCGAP 2013 is the only dedicated document in this regard (Haq et al. 2015; Salehin et al. 2018). Sectoral policies in India have put major emphasis on women's role in agriculture, management of natural resources and empowerment of women with appropriate skill development. They have addressed to some extent women-targeted initiatives with regard to self-employment and small entrepreneurship. Gender issues need mainstreaming in sectoral policies, with a more gender sensitive and inclusive approach, from climate change and disaster management perspective. 
As challenges to attaining national-level goals and climate change targets present significant downside risks and uncertainties which warrant long-term strategies, the government of Bangladesh has developed the Bangladesh Delta Plan 2100 (BDP2100 2018). This aims to integrate sectoral, national and global targets and plans into long-term coherent strategies across government ministries for adaptive delta management taking scenarios of climate change, population growth and economic development into account (BDP2100 2018). The focus is on steering the opportunities and vulnerabilities created by the interface of water, climate change, natural disasters, poverty and environment, with sustainable use of water resources and prevention of water-related natural disasters providing the backbone.

\subsection{Adaptation, Migration and a Way Forward}

The future of the GBM Delta in the Anthropocene has many opportunities, including tremendous potential for economic growth. At the same time, environmental hazards, particularly in so far as impacts are more keenly felt among the vulnerable populations, are a concern. Mitigating hazards offers relief from one side of the equation only; it does not constitute vulnerability reduction. This situation will be exacerbated by climate change during the Anthropocene and presents the countries in the GBM Delta with a variety of significant challenges. The impacts of climate change are expected to disrupt the complex hydrological balance existing in the GBM Delta basin and lead to a range of water management challenges. Factors such as salinity intrusion into rivers have already led to reduction of cropland and an ongoing transition to large-scale aquaculture (Amoako-Johnson et al. 2016). The much lower employment in aquaculture than agriculture leads to migration.

Exacerbating environmental pressures due to global climate and environmental change could create social destabilisation. Social vulnerability is defined as the inability of people, organisations and societies to withstand adverse impacts from the multiple stressors to which they are exposed (Adger 1999; Adger and Kelly 1999). Vulnerability and related characteristics have been characterised for deltas (Chapter 6), including 
coastal Bangladesh (Uddin et al. 2019). Here a first preliminary transboundary assessment of social vulnerability to adverse change is shown for the whole GBM Delta in Fig. 2.7. The analysis is based on Principal Component Analysis of 13 socio-economic variables explained with the rationale in Table 2.1. The data is derived from census data at the sub-district level (Upazila in Bangladesh, and Community Development Block in India) as follows the Census of India and the Bangladesh Bureau of Statistics for 2001 and 2011. The results show that there is a strong vulnerability gradient across the GBM Delta coast in both India and Bangladesh, with the highest vulnerability being closer to the Bay of Bengal. Analysis of the change in social vulnerability from 2001 to 2011 suggests that planned efforts to address poverty, generate non-farm employment and improve health and sanitation status have reduced social vulnerability, while climatic hazards such as the major cyclones of Sidr (2007) and Aila (2009) have increased social vulnerability in

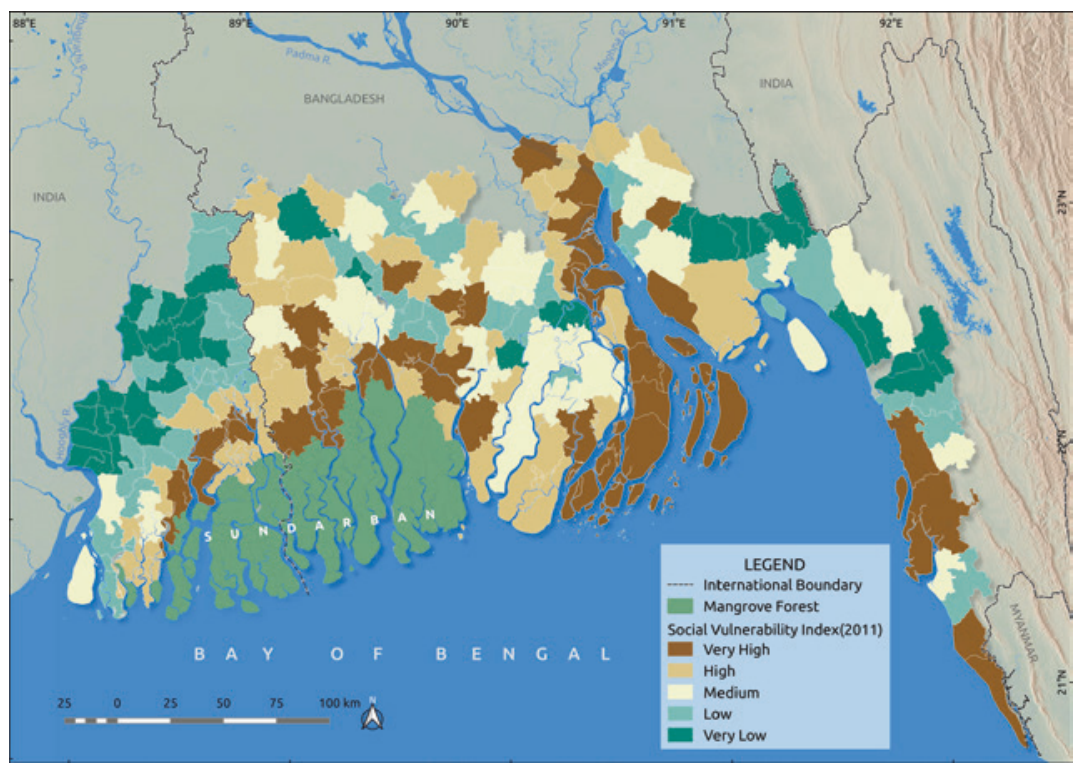

Fig. 2.7 Social Vulnerability Index across the coastal GBM Delta for the year 2011 (see Hazra and Islam 2017; also DECCMA 2018) 
Table 2.1 Description of the socio-economic variables considered in the social vulnerability analysis of the GBM Delta

\begin{tabular}{|c|c|c|}
\hline Variables & & Rationale \\
\hline $\begin{array}{l}\text { Population } \\
\text { density }\end{array}$ & $\begin{array}{l}\text { Number of people per } \\
\text { square kilometre }\end{array}$ & $\begin{array}{l}\text { Areas with high popula- } \\
\text { tion density are more } \\
\text { exposed to climate } \\
\text { change impacts }\end{array}$ \\
\hline $\begin{array}{l}\text { Average household } \\
\text { size }\end{array}$ & $\begin{array}{l}\text { Average number of peo- } \\
\text { ple per household }\end{array}$ & $\begin{array}{l}\text { Families with a large } \\
\text { number of people have } \\
\text { more limited resources } \\
\text { and more work respon- } \\
\text { sibilities that reduce } \\
\text { the resilience to and } \\
\text { recovery from hazards }\end{array}$ \\
\hline Female population & $\begin{array}{l}\text { Percentage of female } \\
\text { population to total } \\
\text { population }\end{array}$ & $\begin{array}{l}\text { Females have a more } \\
\text { difficult time during } \\
\text { recovery from disasters } \\
\text { than males, due to their } \\
\text { family care responsi- } \\
\text { bilities, sector-specific } \\
\text { employment and lower } \\
\text { wages }\end{array}$ \\
\hline Illiteracy rate & $\begin{array}{l}\text { Percentage of illiter- } \\
\text { ate persons to total } \\
\text { population }\end{array}$ & $\begin{array}{l}\text { Illiteracy or lower level } \\
\text { education constrains } \\
\text { the ability to under- } \\
\text { stand warning infor- } \\
\text { mation and access to } \\
\text { recovery information }\end{array}$ \\
\hline $\begin{array}{l}\text { Agricultural } \\
\text { dependency }\end{array}$ & $\begin{array}{l}\text { Percentage of cultivators } \\
\text { and agricultural labours } \\
\text { (dependent on agricul- } \\
\text { ture) to total working } \\
\text { population }\end{array}$ & $\begin{array}{l}\text { Agricultural dependents } \\
\text { are more impacted } \\
\text { by hazard events and } \\
\text { climate variability than } \\
\text { other workers }\end{array}$ \\
\hline Non-workers & $\begin{array}{l}\text { Percentage of total } \\
\text { non-workers (no work } \\
\text { in any economically } \\
\text { productive activity- } \\
\text { students, persons } \\
\text { engaged in household } \\
\text { duties, dependents) to } \\
\text { total population }\end{array}$ & $\begin{array}{l}\text { Non-workers contribute } \\
\text { to a slower recovery } \\
\text { from the disasters }\end{array}$ \\
\hline
\end{tabular}


Table 2.1 (continued)

\begin{tabular}{|c|c|c|}
\hline Variables & & Rationale \\
\hline Kutcha house & $\begin{array}{l}\text { Percentage of households } \\
\text { living in Kutcha (walls } \\
\text { and/or roof are predom- } \\
\text { inantly made by mud, } \\
\text { bamboos, grass, reeds, } \\
\text { thatch, plastic/poly- } \\
\text { thene) houses (tempo- } \\
\text { rary structure) }\end{array}$ & $\begin{array}{l}\text { People living in Kutcha } \\
\text { houses are more vul- } \\
\text { nerable to hazards }\end{array}$ \\
\hline Home ownership & $\begin{array}{l}\text { Percentage of households } \\
\text { that do not own their } \\
\text { home (rented, occupied } \\
\text { and others) }\end{array}$ & $\begin{array}{l}\text { People who don't own } \\
\text { their home have less } \\
\text { access to information } \\
\text { about financial aid } \\
\text { during recovery }\end{array}$ \\
\hline Electricity connection & $\begin{array}{l}\text { Percentage of households } \\
\text { living without mains } \\
\text { electricity connection }\end{array}$ & $\begin{array}{l}\text { Households without } \\
\text { access to safe/improved } \\
\text { sources of drinking }\end{array}$ \\
\hline Drinking water & $\begin{array}{l}\text { Percentage of households } \\
\text { reported 'others' cate- } \\
\text { gory (i.e. ponds/canal/ } \\
\text { spring/river) as the main } \\
\text { source of drinking water }\end{array}$ & $\begin{array}{l}\text { water, electricity con- } \\
\text { nection and sanitation } \\
\text { facility are more sensi- } \\
\text { tive to climate change } \\
\text { impacts. They have the }\end{array}$ \\
\hline Sanitation facility & $\begin{array}{l}\text { Percentage of households } \\
\text { that have no sanitation } \\
\text { facility }\end{array}$ & $\begin{array}{l}\text { lower ability to respond } \\
\text { to and recover from the } \\
\text { impacts of hazards }\end{array}$ \\
\hline Poverty & $\begin{array}{l}\text { Percentage of population } \\
\text { living below the poverty } \\
\text { line }\end{array}$ & $\begin{array}{l}\text { Poor people have lower } \\
\text { access to resources and } \\
\text { lower ability to absorb } \\
\text { losses and enhance } \\
\text { resilience to hazard } \\
\text { impacts }\end{array}$ \\
\hline Rural population & $\begin{array}{l}\text { Percentage of popula- } \\
\text { tion living in rural areas } \\
\text { (total population minus } \\
\text { urban population) }\end{array}$ & $\begin{array}{l}\text { Rural populations are } \\
\text { more dependent on } \\
\text { natural resources and } \\
\text { have lower incomes }\end{array}$ \\
\hline
\end{tabular}

affected sub-districts. Similar issues exist across the GBM Delta in India and Bangladesh, and similar solutions are appropriate.

The delta has limited capacity to deal with current climate and hydrological variability and, without major capacity development, intensification expected from climate change will exacerbate problems 
as the Anthropocene unfolds. The Intergovernmental Panel on Climate Change (IPCC) Fourth Assessment Report (AR4) highlighted South Asia and the greater Himalaya as one of several key regions having greatly divergent predictions of future changes in precipitation. Both climatic and non-climatic events adversely affect the livelihood of the people of this delta. Land loss due to submergence and increasing soil salinity, along with land fragmentation, will result in challenges for the delta livelihoods.

In the GBM Delta, economic reasons dominate people's perception as the important drivers of migration (Arto et al. 2019). However, environmental reasons are also viewed as a component driver; albeit by a smaller percentage of respondents (about 1.5\% people identified environmental degradation or extreme events as the first most important driver, another $5.3 \%$ as the second most important driver and another $10 \%$ as the third most important driver). In the GBM, West Bengal, almost two-thirds of the migrants are moving to seek better employment, followed by family obligations (12.3\%), while 10\% left their origin to pursue a degree or obtain training in a new skill. Only 3\% of the population cited environmental stresses as the direct cause of migration (see Chapter 7). The fact that environmental stresses often precipitate economic stresses also suggests that people do not always clearly perceive the causes of economic stresses. Environmental factors might be playing a bigger role than the numbers suggest. Intentions to migrate in the future are high (among two-thirds of all households), with seeking jobs, better education and environmental stresses as important reasons. Perceived environmental impacts (e.g. flooding, cyclone, erosion), including loss of seasonal income, are apparent in areas more exposed to hazards, indicating a higher probability of future migration from the more hazard-prone areas (see Chapter 7). In policies and plans, migration has not been addressed as a climate change adaptation option, either in Bangladesh or India. In Bangladesh, the emphasis has been on overseas migration, while rural to urban migration has been discouraged. This resulted in adaptation gaps in moulding internal migration into economic benefits. Recent emphasis has been on fostering economic growth and employment opportunities in coastal areas through labour-intensive industries in planned industrial zones. 
Adaptation policies in both India and Bangladesh are mostly disaster focused, lacking sectoral coherence and with little focus on gender-specific adaptation and migration as a climate change adaptation (see Chapter 9). Adaptation policy analysis in Bangladesh has revealed that climate change issues are mostly disaster risk reduction (DRR) focused, with ecosystem-based adaptations and community-based adaptations recently emerging (Haq et al. 2015). Most adaptation measures are infrastructure focused, in alignment with earlier policies, and reactive in nature, with inadequate focus on gender issues. Research has revealed an inventory of implemented adaptations showing that DRR has been the major focus in almost one-fourth of the total adaptations in the country, followed by water resources management (WRM) (20\%), infrastructural development (17\%) and agriculture (13\%). The coastal districts (the delta region), being the most vulnerable region to natural hazards and disasters has received more focus on DRR $(73 \%$ of total DRR adaptations) and WRM (60\% of total WRM adaptations) (Haq et al. 2015). Most of the WRM, DRR and coastal zone management focused adaptations to climate variability and climate change are infrastructural in nature which suggests a priority of implementing organisations (mostly government) towards infrastructural development. Even with the commendable task of preparing BCCSAP 2009 as the first LDC country and having Climate Change Trust Fund (CCTF) in 2010, there has been relatively little emphasis on the capacity building which was a key aspiration in BCCSAP 2009 to better understand climate change risks and improve planning and execution in development projects to combat climate change. Most of the adaptation measures have been implemented in recent decades when climate change manifestations have been clear, though some of the development activities occurring in the twentieth century have served in combating climate change induced disastrous events. Nevertheless, adaptation activities with anticipation of future major hazards have been less in number while the majority have been reactive in nature. This explains why the majority of the adaptations $(75 \%$ in the whole country and $72 \%$ in the coastal delta) are undertaken in response to chronic stresses like 
salinity and waterlogging in the delta region and river bank erosion, regular flood and drought in the non-delta region, rather than sudden shocks like major cyclonic storm surge events and large floods.

The infrastructure focused adaptation initiatives have meant a skewed allocation of adaptation funds across the implementing ministries. Lack of guidance on gender-specific adaptation needs in policies and plans and lack of participation from local people resulted in less than one-fourth of adaptation addressing gender issues. Examination of the projects executed under the Bangladesh CCTF showed that projects executed by the local government institutions (LGIs) were more targeted towards climate change compared to the central government agencies targeting climate variability induced hazards. Gender-sensitive issues were also considered better in adaptation projects implemented by LGIs than projects executed by central Government of Bangladesh agencies. More inclusive planning involving LGIs and NGOs may improve gender-sensitive development and thus overall sustainability of adaptation options.

Agricultural livelihoods, rural development and DRR are the major sectors for adaptation activities in West Bengal. Most of the activities are reactive approaches in response to Cyclone Aila of 2009. More anticipatory approaches such as setting up a Climate Change Adaptation Centre, renewable energy, livelihood development of disadvantaged sections, seed banks, mobile boat dispensary, probable human migration, innovative farming practices are yet to be explored. The majority of the adaptation activities have been undertaken due to 'stress' in the area, while only few have been due to 'shock'. The factors of changing climatic conditions, cyclones and storm surges, breaching of embankments leading to coastal inundation, floods, coastal erosion have been pointed out as the main cause of stress. Apart from this, the other triggers of adaptation include loss of livelihood and income, unemployment, loss of physical assets and lack of proper market linkages. In terms of adaptation providers, the majority of reported adaptations have been provided by the government. 
Bangladesh requires a long-term vision, planning and implementation comprising all government ministries and agencies that contribute to this collective objective. Owing to the large uncertainties with regard to climate change and socio-economic progress, planning, robust and versatile strategies are required for effective Adaptive Delta Management (Seijger et al. 2017; BDP2100 2018). Policymakers from both India and Bangladesh require stronger knowledge and scientific tools to anticipate the dynamic effects of global climate change and their interaction with environmental and socio-economic change and make decisions on the most appropriate interventions and investments (e.g. Nicholls et al. 2018).

Current adaptation practices in the GBM are shown in Fig. 2.8. These vary widely from east to west which are fundamentally triggered by the adaption need at a local environment level that includes stresses due to disasters such as flooding, erosion, salinisation, storm surge, etc. Cross-border learning on effective adaptation practices that require collaborative research on joint GBM issues will promote replicable future adaptations. The provision of effective cyclone warning systems and

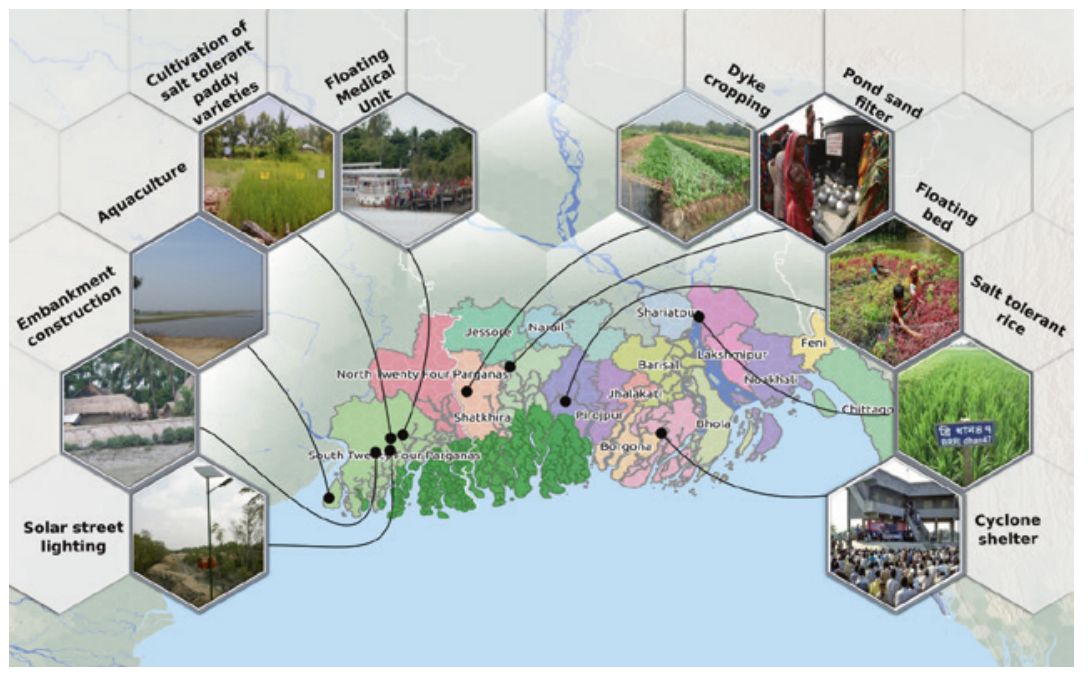

Fig. 2.8 Examples of adaptation options utilised in the GBM Delta 
thousands of cyclone shelters provides one strong example of recent adaptation success in Bangladesh and West Bengal (Lumbroso et al. 2017). Looking to the future, strategic development of tidal river management towards more systematic controlled sedimentation within polders offers the promise of a new innovative response to relative sea-level rise (discussed in more detail in Chapters 5, 6, 11).

\subsection{Conclusions}

Coastal regions of the GBM Delta have long been settled by humans due to their abundant resources for livelihoods, including agriculture, fisheries, transportation and rich biodiversity. However, natural and anthropogenic factors, such as climate change and sea-level rise, and land subsidence, population pressure and developmental activities during the Anthropocene pose threats to the delta's sustainability. Indeed, there is a strong association between household poverty and the likelihood of material and human loss following a natural event in the islands of the Indian GBM. It is also evident that the poorest households are most likely to suffer from deteriorating livelihoods following a natural hazard. The GBM Delta is enriched with ecosystem services that attract many people to live there. However, overexploitation of provisioning ecosystem resources (e.g. agriculture) has led to other important changes such as declining water quality and higher salinisation during the Anthropocene.

A key characteristic of the Anthropocene delta has been the progressive land use change driven by the introduction of large-scale aquaculture, partially for financial reasons and partially in response the progressive increase in salinity driven by rising sea-levels and hydrological mismanagement in the upper delta systems. This aquaculture development is on a large and highly commercialised scale and offers limited local employment as well as a poor record in sustainability, as soils are heavily polluted/salinised within a few years of operation. As a result, aquaculture, while lucrative to those who invest in it, contributes to the loss of livelihoods of the poorest sectors of the community and consequently migration out of the region. 
This supports an ongoing migratory trend, predominantly due to economic drivers, from the delta.

The growing populations of the two associated delta megacities (Dhaka and Kolkata) indicate continuous in-migration in recent years. This produces a population that is highly vulnerable within the urban environment, subject to poor working and wage conditions and highly susceptible to urban climatic change. Making these two cities sustainable in the long run requires greater policy recognition of the drivers of migration and their fundamentally economic underpinnings, and more specifically that people will continue to migrate to access urban benefits. Indeed, it is perhaps better to undertake a strategy of bringing the urban benefits to those in rural areas, such as improved infrastructure and development of smaller distributed cities and the health, economic, livelihood and education benefits that entails than simply aiming to enhance standard rural livelihoods. As such, in the Anthropocene it is vital that the delta is understood and developed as a system, considering both the urban and rural areas, which will feed the cities and sustain biodiversity, and all the threats and opportunities are considered. This is consistent with evidence-based Adaptive Delta Planning as proposed in the BDP2100 (2018).

\section{References}

Adger, W. N. (1999). Social vulnerability to climate change and extremes in coastal Vietnam. World Development, 27(2), 249-269. https://doi. org/10.1016/S0305-750X(98)00136-3.

Adger, W. N., Adams, H., Kay, S., Nicholls, R. J., Hutton, C. W., Hanson, S. E., et al. (2018). Ecosystem services, well-being and deltas: Current knowledge and understanding. In R. J. Nicholls, C. W. Hutton, W. N. Adger, S. E. Hanson, M. M. Rahman, \& M. Salehin (Eds.), Ecosystem services for well-being in deltas: Integrated assessment for policy analysis (pp. 3-27). Cham: Springer. https://doi.org/10.1007/978-3-319-71093-8_1.

Adger, W. N., \& Kelly, P. M. (1999). Social vulnerability to climate change and the architecture of entitlements. Mitigation and Adaptation Strategies for Global Change, 4(3), 253-266. https://doi.org/10.1023/A:1009601904210. 
Alam, M. (1996). Subsidence of the Ganges-Brahmaputra Delta of Bangladesh and associated drainage, sedimentation and salinity problems. In J. D. Milliman \& B. U. Haq (Eds.), Sea-level rise and coastal subsidence: Causes, consequences, and strategies (pp 169-192). Dordrecht, The Netherlands: Springer. https://doi.org/10.1007/978-94-015-8719-8_9.

Alley, K. D., Hile, R., \& Mitra, C. (2014). Visualizing hydropower across the Himalayas: Mapping in a time of regulatory decline. Himalaya, the Journal of the Association for Nepal and Himalayan Studies, 34(2), 9.

Allison, M. A. (1998). Historical changes in the Ganges-Brahmaputra Delta front. Journal of Coastal Research, 14(4), 1269-1275.

Allison, M. A., Khan, S. R., Goodbred, S. L., \& Kuehl, S. A. (2003). Stratigraphic evolution of the late Holocene Ganges-Brahmaputra lower delta plain. Sedimentary Geology, 155(3), 317-342. https://doi. org/10.1016/S0037-0738(02)00185-9.

Amoako-Johnson, F., Hutton, C. W., Hornby, D., Lázár, A. N., \& Mukhopadhyay, A. (2016). Is shrimp farming a successful adaptation to salinity intrusion? A geospatial associative analysis of poverty in the populous Ganges-Brahmaputra-Meghna Delta of Bangladesh. Sustainability Science, 11(3), 423-439. https://doi.org/10.1007/s1 1625-016-0356-6.

Arto, I., García-Muros, X., Cazcarro, I., González, M., Markandya, A., \& Hazra, S. (2019). The socioeconomic future of deltas in a changing environment. Science of the Total Environment, 648, 1284-1296. https://doi. org/10.1016/j.scitotenv.2018.08.139.

BBS. (2015). Population density and vulnerability: A challenge for sustainable development of Bangladesh. Population Monograph No. 7. Bangladesh Bureau of Statistics (BBS), Ministry of Planning, Government of the People's Republic of Bangladesh. http://203.112.218.65:8008/ PageWebMenuContent.aspx?MenuKey=243. Last accessed 5 December 2018.

BDP2100. (2018). Bangladesh Delta Plan 2100. Volumes 1-Strategy and 2-Investment Plan. Dhaka, Bangladesh, General Economics Division (GED), Bangladesh Planning Commission, Government of the People's Republic of Bangladesh. https://www.bangladeshdeltaplan2100.org/. Last accessed 8 October 2018.

Biswas, A. K. (1992). Indus water treaty: The negotiating process. Water International, 17(4), 201-209. https://doi.org/10.1080/02508069208686140. Brown, S., \& Nicholls, R. (2015). Subsidence and human influences in mega deltas: The case of the Ganges-Brahmaputra-Meghna. Science of the Total Environment, 527, 362-374. https://doi.org/10.1016/j.scitotenv.2015.04.124. 
Census of India. (2011). Table A2 area, population, decennial growth rate and density for 2001 and 2011 at a glance for West Bengal and the districts. Office of the Registrar General and Census Commissioner, Government of India. http://censusindia.gov.in/2011-prov-results/prov_data_products_wb.html. Last accessed 5 November 2018.

Dastagir, M. R. (2015). Modeling recent climate change induced extreme events in Bangladesh: A review. Weather and Climate Extremes, 7, 49-60. https://doi.org/10.1016/j.wace.2014.10.003.

DECCMA. (2018). Climate change, migration and adaptation in deltas: Key findings from the DECCMA project (Deltas, Vulnerability and Climate Change: Migration and Adaptation [DECCMA] Report). Southampton, UK: DECCMA Consortium. https://www.preventionweb.net/publications/ view/61576. Last accessed 27 November 2018.

Dey, S., Ghosh, A. K., \& Hazra, S. (2016). Review of West Bengal State adaptation policies, Indian Bengal Delta (Deltas, Vulnerability and Climate Change: Migration and Adaptation [DECCMA] Working Paper). Southampton, UK: DECCMA Consortium. https://generic.wordpress.soton.ac.uk/deccma/resources/working-papers/. Last accessed 6 August 2018.

Ericson, J. P., Vörösmarty, C. J., Dingman, S. L., Ward, L. G., \& Meybeck, M. (2006). Effective sea-level rise and deltas: Causes of change and human dimension implications. Global and Planetary Change, 50(1-2), 63-82. https://doi.org/10.1016/j.gloplacha.2005.07.004.

Ghosh, S. (2017). Land reforms, agitations, tensions in Malda and West Dinajpur: Tebhaga to Naxalbari. International Journal for Innovative Research in Multidisciplinary Field, 3(5), 163-168.

Goodbred, S. L., \& Kuehl, S. A. (1998). Floodplain processes in the Bengal Basin and the storage of Ganges-Brahmaputra river sediment: An accretion study using 137Cs and 210Pb geochronology. Sedimentary Geology, 121(3), 239-258. https://doi.org/10.1016/S0037-0738(98)00082-7.

Gopal, B., \& Chauhan, M. (2006). Biodiversity and its conservation in the Sundarban Mangrove Ecosystem. Aquatic Sciences, 68(3), 338-354. https:// doi.org/10.1007/s00027-006-0868-8.

Hajra, R., \& Ghosh, T. (2018). Agricultural productivity, household poverty and migration in the Indian Sundarban Delta. Elementa Science of the Anthropocene, 6(1), 3. https://doi.org/10.1525/elementa.196.

Haq, M. I., Omar, M. A. T., Zahra, Q. A., Shashi, I. J., \& Rahman, M. R. (2015). Evaluation of adaptation policies in GBM Delta of Bangladesh (Deltas, Vulnerability and Climate Change: Migration and Adaptation [DECCMA] Working Paper). Southampton, UK: DECCMA Consortium. 
https://generic.wordpress.soton.ac.uk/deccma/resources/working-papers/. Last accessed 19 November 2018.

Haque, A., \& Nicholls, R. J. (2018). Floods and the Ganges-BrahmaputraMeghna Delta. In R. J. Nicholls, C. W. Hutton, W. N. Adger, S. E. Hanson, M. M. Rahman, \& M. Salehin (Eds.), Ecosystem services for well-being in deltas: Integrated assessment for policy analysis (pp. 147-159). Cham: Springer. https://doi.org/10.1007/978-3-319-71093-8_8.

Hazra, S., \& Islam, N. (2017, April 23-28). A preliminary assessment of social vulnerability in Ganga-Brahmaputra-Meghna Delta. EGU General Assembly, Vienna, Austria. European Geosciences Union.

Islam, A. S., Haque, A., \& Bala, S. K. (2010). Hydrologic characteristics of floods in Ganges-Brahmaputra-Meghna (GBM) Delta. Natural Hazards, 54(3), 797-811. https://doi.org/10.1007/s11069-010-9504-y.

Kuehl, S. A., Hariu, T. M., \& Moore, W. S. (1989). Shelf sedimentation off the Ganges-Brahmaputra river system: Evidence for sediment bypassing to the Bengal fan. Geology, 17(12), 1132-1135.

Lumbroso, D. M., Suckall, N. R., Nicholls, R. J., \& White, K. D. (2017). Enhancing resilience to coastal flooding from severe storms in the USA: International lessons. Natural Hazards and Earth System Sciences, 17(8), 1357-1373. https://doi.org/10.5194/nhess-17-1357-2017.

Milliman, J. D., \& Meade, R. H. (1983). World-wide delivery of river sediment to the oceans. The Journal of Geology, 91(1), 1-21. https://doi. org/10.1086/628741.

Morgan, J. P., \& McIntire, W. G. (1959). Quaternary geology of the Bengal basin, East Pakistan and India. Geological Society of America Bulletin, 70(3), 319-342.

Mortreux, C., Safra de Campos, R., Adger, W. N., Ghosh, T., Das, S., Adams, H., et al. (2018). Political economy of planned relocation: A model of action and inaction in government responses. Global Environmental Change, 50, 123-132. https://doi.org/10.1016/j.gloenvcha.2018.03.008.

Nicholls, R. J., Hutton, C., Adger, W. N., Hanson, S. E., Rahman, M. M., \& Salehin, M. (Eds.). (2018). Ecosystem services for well-being in deltas: Integrated assessment for policy analysis. London, UK: Palgrave Macmillan.

Noor, S. (2018). Investigation of polderization induced water logging and feasible adaptation measures in Dumuria Upazila under Khulna Districts (Unpublished Masters thesis). Institute of Water and Flood Management, BUET, Dhaka, Bangladesh.

Rahman, M., Dustegir, M., Karim, R., Haque, A., Nicholls, R. J., Darby, S. E., et al. (2018). Recent sediment flux to the Ganges-Brahmaputra-Meghna 
Delta system. Science of the Total Environment, 643, 1054-1064. https:// doi.org/10.1016/j.scitotenv.2018.06.147.

Raman, K. S., Kumar, S., \& Neogi, B. B. (1986). Exploration in Bengal Basin India-An overview. Singapore: Offshore South East Asia Show. Society of Petroleum Engineers. https://doi.org/10.2118/14598-MS.

Rudra, K. (2018). Conflicts over sharing the waters of transboundary rivers. In Rivers of the Ganga-Brahmaputra-Meghna Delta (pp. 163-172). Cham: Springer.

Salehin, M., Rahman, R., Allan, A., Hossen, M. A., Chowdhury, A., \& Sayan, C. (2018). Challenges of governance system in addressing climate change adaptation measures in Bangladesh: Gaps, strengths and opportunities (Deltas, Vulnerability and Climate Change: Migration and Adaptation [DECCMA] Policy Brief). Southampton, UK: DECCMA Consortium. http://generic. wordpress.soton.ac.uk/deccma/resources/briefs/. Last accessed 7 January 2019.

Sarker, M. H., Akter, J., \& Rahman, M. M. (2013). Century-scale dynamics of the Bengal delta and future development. In Proceedings of the International Conference on Water and Flood Management (pp. 91-104). Dhaka, Bangladesh. https://edepot.wur.nl/317989. Last accessed 20 August 2018.

Seijger, C., Douven, W., van Halsema, G., Hermans, L., Evers, J., Phi, H. L., et al. (2017). An analytical framework for strategic delta planning: negotiating consent for long-term sustainable delta development. Journal of Environmental Planning and Management, 60(8), 1485-1509. https://doi. org/10.1080/09640568.2016.1231667.

Uddin, M. N., Saiful Islam, A. K. M., Bala, S. K., Islam, G. M. T., Adhikary, S., Saha, D., et al. (2019). Mapping of climate vulnerability of the coastal region of Bangladesh using principal component analysis. Applied Geography, 102, 47-57. https://doi.org/10.1016/j.apgeog.2018.12.011.

Woodroffe, C. N., Nicholls, R. J., Saito, Y., Chen, Z., \& Goodbred, S. L. (2006). Landscape variability and the response of Asian megadeltas to environmental change. In N. Harvey (Ed.), Global change and integrated coastal management: The Asia-Pacific region (pp. 277-314). New York, NY: Springer. 
Open Access This chapter is licensed under the terms of the Creative Commons Attribution 4.0 International License (http://creativecommons. org/licenses/by/4.0/), which permits use, sharing, adaptation, distribution and reproduction in any medium or format, as long as you give appropriate credit to the original author(s) and the source, provide a link to the Creative Commons license and indicate if changes were made.

The images or other third party material in this chapter are included in the chapter's Creative Commons license, unless indicated otherwise in a credit line to the material. If material is not included in the chapter's Creative Commons license and your intended use is not permitted by statutory regulation or exceeds the permitted use, you will need to obtain permission directly from the copyright holder. 